\title{
Environmental Determinants Influencing Fish Community Structure and Diversity in Two Distinct Seasons among Wetlands of Northern Region (Ghana)
}

\author{
Collins Ayine Nsor ${ }^{1}$ and Edward Adzesiwor Obodai ${ }^{2}$ \\ ${ }^{1}$ Department of Ecotourism and Forest Recreation, Kwame Nkrumah University of Science and Technology, Kumasi, Ghana \\ ${ }^{2}$ Department of Fisheries and Aquatic Sciences, University of Cape Coast, University Post Office, Cape Coast, Ghana \\ Correspondence should be addressed to Collins Ayine Nsor; ayineus@yahoo.com
}

Received 6 November 2015; Revised 14 February 2016; Accepted 28 February 2016

Academic Editor: Jean-Guy Godin

Copyright (C) 2016 C. A. Nsor and E. A. Obodai. This is an open access article distributed under the Creative Commons Attribution License, which permits unrestricted use, distribution, and reproduction in any medium, provided the original work is properly cited.

\begin{abstract}
Fish community structure was assessed in six wetlands using cast nets, to correlate with environmental variables with diversity and distribution patterns, from 2010 to 2012. A total of 2,239 individuals belonging to 44 species and 1,938 individuals belonging to 40 species were sampled in the dry and wet seasons. Mochokid and Mormyrid families dominated fish community and constituted $14.8 \%$, respectively, followed by Alestids (12.9\%) and Chlariids (11.1\%). Rarer taxons were centropomids, channids, malapteruds, and oesteoglossids and represented $1.9 \%$, respectively. Overall, CPUE per net did not vary significantly (Tukey HSD test, $p=0.27$ ) in the dry and wet seasons. Wuntori marsh consistently showed dominance in mean monthly CPUE per net (dry $=115 \pm 4.5$; wet $=107 \pm 7.7$ seasons), while Bunglung constructed wetland was the least recorded (dry $=56.5 \pm 6.2$; wet $=58.3 \pm 4.1$ seasons). Fish diversity and richness differed significantly $(F=0.11, p=0.03)$ among seasons. Environmental disturbances were season-specific and did not differ significantly $(F=0.16 \mathrm{df}=14, p=0.97)$ among sites. A DCA ordination explained $69 \%$ variability in fish distribution patterns, while PCA showed that $81.8 \%$ of nitrate-nitrogen, phosphate, and grazing intensity on axis 1 and conductivity, temperature, and turbidity on axis 2 influenced fish community structure. Wetland conservation must be promoted to sustain fish abundance and overall ecosystem stability.
\end{abstract}

\section{Introduction}

The formation of freshwater systems thousands of years ago initially guided the fish assemblage and distribution patterns that we observe today [1]. However, human activities have largely altered aquatic landscapes through resource exploitation and other impacts. The Millennium Ecosystem Assessment Report [2] estimated that about $20 \%$ of the world's 10,000 freshwater fish species are listed as threatened, endangered, or extinct in the last few decades, partly due to human-led activities. The decline in fish populations is attributed to degradation in water quality [3-5] and periodic phenomena of low-flows and floods, habitat complexity, and agricultural and urban land use [6, 7]. Menzel et al. [8] explained how agriculture activities have had multiple effects on Great Plains streams in the US, including increased turbidity, siltation, and nutrients through soil erosion and irrigation return flows. Erosion and sediment alter substrate characteristics, leading to a decrease in fish species that require clean gravel for spawning [9]. These disturbances on wetland systems may lead to changes in fish community composition and spatial distribution. Variability in fish assemblages is generally influenced by landscape features [10], stream size, and elevation [11] and stocking of economically important exotic/invasive fishes (e.g., brown trout, grayling, carp, and pike) [12] (Pivnička and Humpl, 2004).

Ansari et al. [13] showed how fish species segregate into seasonal groups, as a result of changes in physicochemical parameters, such as salinity, temperature, and dissolved oxygen concentration. The vulnerability of fish from 
the slightest disturbances in their environment is due to the intimate contact of the skin and gills with the surrounding water [14].

Ghana's water resources have been under increasing threat of pollution in recent years due to rapid demographic changes, which have coincided with the establishment of human settlements lacking appropriate sanitary infrastructure [15]. The rising demand for fish and other resources, due to increase in impoverished population in communities close to wetland areas of Northern Region of Ghana, has partly contributed to widespread environmental disturbances. For instance, the use of dynamite as one illegal method of fishing depletes water quality and renders it unwholesome for domestic use and impairs aquatic life. These disturbances are seasonal-specific (i.e., wet and dry seasons) and fish responses vary by season and spatiotemporal scales. Given the high conservation concern of wetlands in Northern Region of Ghana [16], the wise use of these ecosystems, which involves the maintenance of ecological integrity and sustainable exploitation of fish, for the continuous benefit to current and future generations, must be given critical attention.

Researchers in the fisheries field are acutely conscious of the overfishing problem associated with the unregulated or poorly regulated common-use conditions that have prevailed in most fisheries [17]. Many industrialized countries have management regimes for introduced fisheries designed to curb overexploitation and produce better net returns from the fishery, but with modest success. Attempts to manage fisheries in developing countries have been much weaker and most often have had little effect [17]. Thus, fisheries management must be of priority concern, especially to rural communities whose livelihood largely depends on the availability of fish resource.

Understanding the factors influencing seasonal variations on fish community structure, diversity and spatial distribution in Northern Region of Ghana, remains poor. Although native fishermen have observed reduction in fish composition and distribution in recent times, the observed seasonal changes have not been sufficiently investigated to establish the cause of these trends. This study attempts to apply multivariate techniques to establish the environmental determinants influencing the seasonal changes on fish community structure and distribution in six selected wetlands in the Northern Region of Ghana. Our main objective is to (1) quantify fish diversity and (2) examine the responses of fish community composition and spatial distribution to major environmental factors in the six different wetland types.

\section{Materials and Methods}

The study was in six wetlands located in the Northern Region of Ghana, with their coordinates as follows: (i) Wuntori $\left(\mathrm{N}_{0}^{\circ} 08.335^{\prime} \mathrm{W}^{\circ} 0^{\circ} 109^{\circ} .685^{\prime}\right)$; (ii) Kukobila (N10 $08.723^{\prime}$ W000 $\left.48.179^{\prime}\right)$; (iii) Tugu $\left(\mathrm{N}_{0} 9^{\circ} 22.550^{\prime} \mathrm{W}^{\circ} 00^{\circ} 35.004^{\prime}\right)$; (iv) Bunglung (N09 $\left.35.576^{\prime} \mathrm{W}^{\circ} 000^{\circ} 47.443^{\prime}\right)$; (v) Adayili

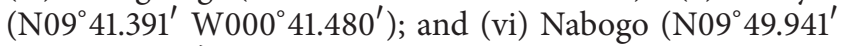
$\mathrm{W} 000^{\circ} .51 .942^{\prime}$ ) (Figure 1). All six sites lie on the extensive floodplain along the course of the White Volta River, which has become incised and modified through meandering and aligning along various topographic features. This has led to the development of streams that have diverted from the main White Volta [18]. All six wetlands were classified as close shallow marshes (Wuntori and Tugu wetlands), open deep marsh (Kukobila wetland), riparian wetlands (Adayili and Nabogo wetlands), and an artificial wetland (Bunglung wetland). The hydrological regimes of the six wetlands were typical of permanent wetlands, whose depth at low tide did not exceed $2 \mathrm{~m}$ on average. Area of the wetlands was quantified through on-screen digitizing of Landsat aerial images, obtained from Google Earth (October, 2012): (a) Wuntori $=7.7$ ha; (b) Kukobila $=5$ ha; (c) Tugu $=2.7$ ha; (d) Nabogo = 7.9 ha; $(\mathrm{e})$ Adayili $=6.7$ ha; and (f) Bunglung = 11.5 ha. Annual rainfall ranges from 1000 to $1,300 \mathrm{~mm}$ per annum and the wet season from June to early October, while the dry season lasts from November to May. Average air temperature varies between $14^{\circ} \mathrm{C}$ and $40^{\circ} \mathrm{C}$ (Slaymaker and Blench, 2002). Altitude ranges between 108 and 138 meters above mean sea level. The vegetation cover is a mixture of grassland dominated by Leersia hexandra and woodland dominated by Mahogany (Khaya senegalensis) and shea tree (Vitellaria paradoxa) interspersed with shrubby communities of Mitragyna inermis and Ziziphus abyssinica. The trees are relatively short with thick bark and occlusions, signifying their adaptation to the cyclical dry season bush fires. Crop farming, livestock rearing, and fishing are the main activities among the inhabitants.

2.1. Fish and Water Quality Sampling Procedure. Since one of the objectives of this study was to quantify fish diversity, richness, and abundance, fish were sampled using cast nets of $3 \mathrm{~cm}$ mesh size and $5 \mathrm{~m}$ radius. Sampling commenced from November to February in the dry season and from July to October in the wet season (2010-2012). Each of the six wetlands (Wuntori, Kukobila, Tugu, Adayili, Nabogo, and Bunglung) was sampled four times each month (once per week), between 08 and 1300 hours. Five net throws per hour of sampling effort were carried out in each site. The total of sampling hours of net throws per site was four hours. Fish were identified in situ to species, with keys developed by Dankwa et al. [19] and Paugy et al. [20]. Species that could not be identified were placed in marked transparent wash bottles, containing formalin solution and sent to the Water Research Institute (WRI) in Tamale, Northern Region of Ghana, for identification.

A total of 11 physicochemical parameters and four anthropogenic factors were determined at all sites on the same day of fish collection. They included $\mathrm{pH}$, turbidity, water temperature, conductivity, TDS, nitrate- $\mathrm{N}\left(\mathrm{NO}_{3}-\mathrm{N}\right)$, phosphate $\left(\mathrm{PO}_{4}\right)$, ammonia $\left(\mathrm{NH}_{4}-\mathrm{N}\right)$, calcium, magnesium, dissolved oxygen, fire, grazing intensity, erosion, and local farming activities. Water samples were collected monthly (in dry and wet seasons), using a clean polyethylene bottle, at three sample stations: upper, mid, and downstream over a 2 -year period. With the exception of $\mathrm{pH}$ and water temperatures that were measured in situ using a portable $\mathrm{pH}$ meter and mercury-in-glass thermometer, respectively, the remaining samples were stored in ice chest and transported 


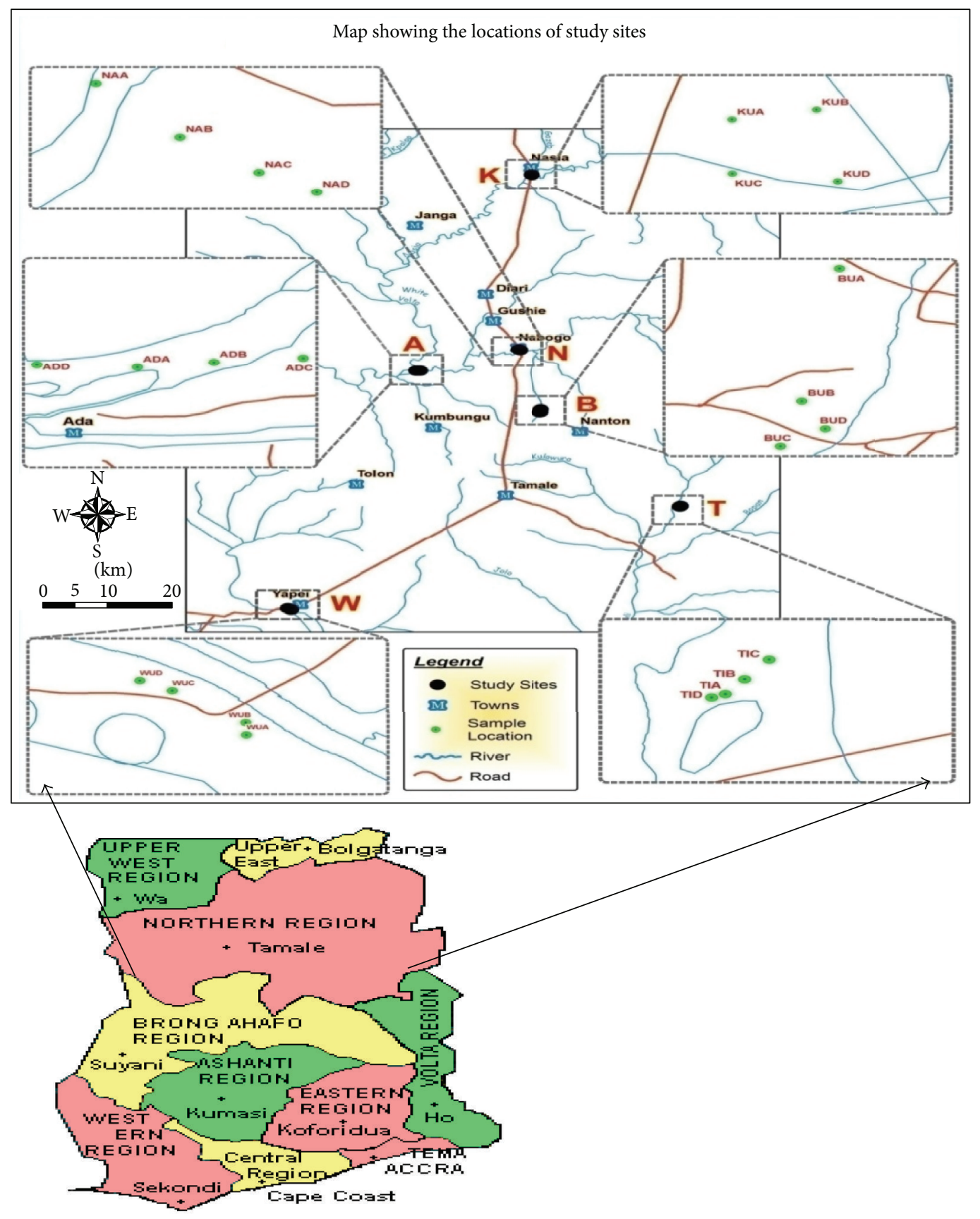

Figure 1: Map of the study areas, showing the location of the wetlands in the floodplains of the White Volta River catchment, Northern Region. The letters represent names of the wetlands; $\mathrm{K}=$ Kukobila, $\mathrm{N}=$ Nabogo, $\mathrm{A}=$ Adayili, $\mathrm{B}=\mathrm{Bunglung}$, $\mathrm{T}=\mathrm{Tugu}$, and $\mathrm{W}=\mathrm{Wuntori}$.

the same day to the Water Research Institute laboratory, for analysis of physicochemical constituents, following the APHA [21] Standard Methods for the Examination of Water and Wastewater.

Four environmental drivers of change or disturbance were bushfire, farming activities grazing, and erosion. Drivers were assessed to determine the severity of these threats on birds' habitat, since bird abundance and diversity are largely influenced by habitat quality. The hierarchical classification of these threats was comprehensive (containing all possible items, at least at higher levels of the hierarchy), consistent (ensuring that entries at a given level of the classification are of the same type), expandable (enabling new items to be added to the classification if they are discovered), and exclusive (allowing any given item to only be placed in one cell within the hierarchy) [22]. A score ranging from 1 to 4 (1 is the least impact and 4 the highest impact) was used to assess scope and severity of every threat. For "scope" we referred to the percentage ratio of the study area affected by a specific threat within the last 5 years (where $100 \%$ correspond to total 
TABLE 1: Mean monthly catch per unit effort per net (CPUE) during the dry (November-February) and wet (July-October) seasons, in the six sites.

\begin{tabular}{|c|c|c|c|c|c|c|}
\hline Sites & 1st month & 2nd month & 3rd month & 4th month & Total & Mean CPUE \pm SE \\
\hline \multicolumn{7}{|c|}{ Dry season } \\
\hline Wuntori & 120 & 111 & 105 & 125 & 461 & $115.3 \pm 4.5$ \\
\hline Kukobila & 85 & 101 & 81 & 99 & 366 & $91.5 \pm 5.0$ \\
\hline Tugu & 93 & 77 & 60 & 75 & 305 & $76.3 \pm 6.8$ \\
\hline Nabogo & 100 & 128 & 103 & 102 & 433 & $108.3 \pm 6.6$ \\
\hline Adayili & 140 & 108 & 90 & 110 & 448 & $112 \pm 10.4$ \\
\hline Bunglung & 71 & 59 & 41 & 55 & 226 & $56.5 \pm 6.2$ \\
\hline Total & & & & & 2,239 & \\
\hline \multicolumn{7}{|c|}{ Wet season } \\
\hline Wuntori & 102 & 103 & 95 & 130 & 430 & $107.5 \pm 7.7$ \\
\hline Kukobila & 81 & 70 & 64 & 86 & 301 & $75.3 \pm 5.0$ \\
\hline Tugu & 47 & 34 & 57 & 43 & 181 & $47.5 \pm 3.3$ \\
\hline Nabogo & 115 & 97 & 105 & 88 & 405 & $101.3 \pm 5.8$ \\
\hline Adayili & 71 & 117 & 93 & 107 & 388 & $97 \pm 10.0$ \\
\hline Bunglung & 69 & 51 & 60 & 53 & 233 & $58.3 \pm 4.1$ \\
\hline Total & & & & & 1,938 & \\
\hline
\end{tabular}

site area: $\chi$ ha) [23]. The scores were assigned as follows: 4: the threat is found throughout (50\%) the site area; 3: the threat is spread in $15-50 \%$ of the study area; 2 : the threat is scattered $(5-15 \%)$; and 1 : the threat is localized $(<5 \%)$.

Assessment of the disturbed area was carried out within a $1.2 \mathrm{~km}$ radius starting from the hydric delineated zone of the wetland. This was because all land use activities assessed were observed within the stated radius following a preliminary survey of the wetlands.

2.2. Statistical Analysis. The Shannon-Weiner index was calculated to determine the current status of fish community composition. Shannon-Weiner index equation is expressed as

$$
H^{\prime}=-\sum_{i=1}^{s} p i(\ln p i),
$$

(see [24]) where $s$ is the number of species and $p i$ is the proportion of individuals or the abundance of the $i$ th species expressed as a proportion of the total cover and $\ln$ is a natural logarithm (Shannon and Wiener, 1963). Margalef's index (D) of species richness that controls for sample size was calculated as

$$
D=\frac{(S-1)}{\ln N}
$$

(see [25]), where $S$ is the number of species, $\ln$ is a natural logarithm, and $N$ is the number of sites. A one-way ANOVA was applied to test for the differences in species diversity and species richness among the six wetlands, using SPSS version 20. A Kruskal-Wallis test was applied to test the differences in the mean of the diversity indices between riparian wetlands and the marshes.

We used detrended correspondence analysis (DCA) (an indirect ordination method of gradient analysis), to identify the strongest gradients of fish assemblage variation across the six wetlands. This was followed by principal component analysis (PCA) ver. 1.41 [26], to evaluate the variability in assemblage structure, diversity, and preferred wetland type in relation to the environmental variables. DCA was used primarily to determine the compositional variation of fish species in the respective wetlands, while PCA was performed to examine the relationship between fish species distribution and associated environmental gradients or variables. DCA techniques have the ability to handle large, complex data sets and uncover long ecological gradients, as well as help in data reduction and exploration [27, 28]. Environmental variables were $\log _{10}$ transformed when their variances were much larger than their means. This was followed by a one-way ANOVA test to determine whether environmental variables differed significantly among all sites. A Monte Carlo permutation test (9999 permutations) was used to test for the significance of the eigenvalues generated by the first three axes in the analyses of fish assemblage structure to environmental variables.

\section{Results}

Overall, 2,239 individuals from 44 species and belonging to 16 families were sampled in the dry season, while 1,938 individuals belonging to 40 species and from 12 families were identified during the wet season (Tables 1 and 2). Wuntori marsh contained the highest fish abundance in the dry season, closely followed by Adayili and Nabogo riparian systems and the lowest abundance was from Bunglung constructed wetland (Table 1). Similar patterns in species abundance were found in the six sites during the wet season. Fishes in the family Mochokidae were the most abundant and constituted $15.4 \%$ of the taxon, followed by Alestids (13.4\%) and Clariids (11.5\%) (Table 2). Rarer taxons were centropomids, channids, malapteruds, and osteoglossids and represented $1.9 \%$, respectively. Mean monthly catch per unit 
TABLE 2: Relative abundance of fish species recorded in the six sites, during the dry and wet seasons. $(-)=$ absent.

\begin{tabular}{|c|c|c|c|}
\hline Family & Species & Dry season & Wet season \\
\hline \multirow{7}{*}{ Alestidae } & Alestes dentex & 129 & 108 \\
\hline & Alestes baremoze & 64 & 71 \\
\hline & Brycinus nurse & 160 & 155 \\
\hline & Brycinus macrolepidotus & 92 & 24 \\
\hline & Hydrocynus brevis & 17 & - \\
\hline & Hydrocynus forskali & 4 & - \\
\hline & Micralestes occidentalis & - & 83 \\
\hline \multirow{2}{*}{ Bagridae } & Bagrus bajad & 47 & - \\
\hline & Bagrus docmac & 3 & - \\
\hline \multirow{5}{*}{ Cichlidae } & Oreochromis niloticus & 297 & 202 \\
\hline & Sarotherodon galilaeus & 342 & 154 \\
\hline & Chromidotilapia guntheri & 10 & - \\
\hline & Tilapia dageti & 19 & 81 \\
\hline & Tilapia zilli & - & 61 \\
\hline \multirow{2}{*}{ Citharinidae } & Citharinus citharus & 28 & - \\
\hline & Citharinus latus & 5 & - \\
\hline Centropomidae & Lates niloticus & 28 & 8 \\
\hline Channidae & Parachanna obscura & 20 & 6 \\
\hline \multirow{6}{*}{ Clariidae } & Clarias gariepinus & 99 & 32 \\
\hline & Clarias anguillaris & 38 & 80 \\
\hline & Heterobranchus bidorsalis & 77 & 15 \\
\hline & Clarias laeviceps & - & 19 \\
\hline & Clarias camerunensis & - & 6 \\
\hline & Heterobranchus longifilis & - & 7 \\
\hline \multirow{2}{*}{ Claroteidae } & Auchenoglanis occidentalis & 98 & 109 \\
\hline & Chrysichthys auratus & 6 & - \\
\hline \multirow{4}{*}{ Cyprinidae } & Labeo coubie & 139 & 41 \\
\hline & Labeo senegalensis & 103 & 99 \\
\hline & Labeo parvus & 9 & 15 \\
\hline & Raimas nigeriensis & - & 12 \\
\hline \multirow{2}{*}{ Distichodontidae } & Distichodus engycephalus & 25 & - \\
\hline & Distichodus rostratus & 7 & - \\
\hline \multirow{8}{*}{ Mochokidae } & Synodontis clarias & 42 & 38 \\
\hline & Synodontis membranaceus & 9 & 13 \\
\hline & Synodontis eupterus & 35 & - \\
\hline & Synodontis schall & 90 & 86 \\
\hline & Synodontis nigrita & 12 & 36 \\
\hline & Synodontis velifer & 85 & 8 \\
\hline & Hemisynodontis membranaceus & 7 & 11 \\
\hline & Synodontis bastiani & - & 12 \\
\hline Malapteruridae & Malapterurus electricus & 6 & 2 \\
\hline \multirow{8}{*}{ Mormyridae } & Hyperopisus bebe & 13 & 18 \\
\hline & Hyppopotamyrus paugyi & - & 2 \\
\hline & Marcusenius senegalensis & 102 & 100 \\
\hline & Mormyrus hasselquistii & 1 & - \\
\hline & Mormyrus rume & 10 & 51 \\
\hline & Petrocephalus bovei & 20 & 14 \\
\hline & Mormyrus delicious & - & 10 \\
\hline & Mormyrops breviceps & - & 4 \\
\hline Osteoglossidae & Hetrotis niloticus & 14 & 12 \\
\hline \multirow{2}{*}{ Schilbeidae } & Schilbe intermedius & 131 & 90 \\
\hline & Schilbe mystus & 17 & 33 \\
\hline \multirow{2}{*}{ Polypteridae } & Polypterus senegalus senegalus & 5 & - \\
\hline & Polypterus endlicheri & 24 & 7 \\
\hline Total & & 2,239 & 1,938 \\
\hline
\end{tabular}




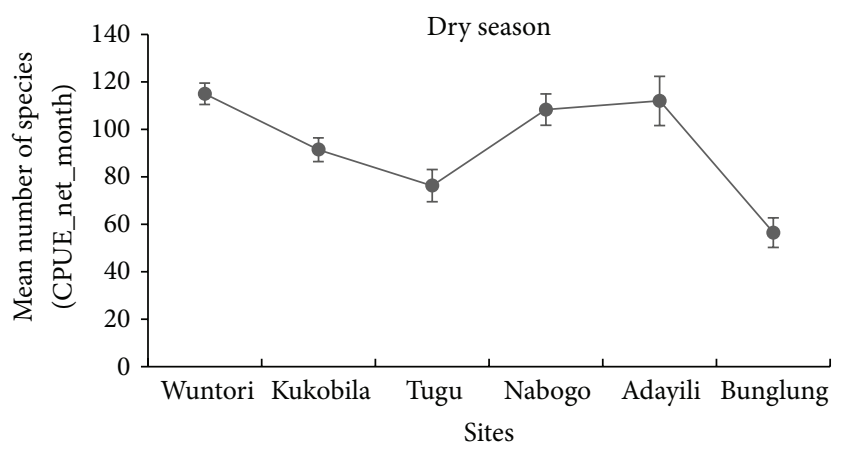

(a)

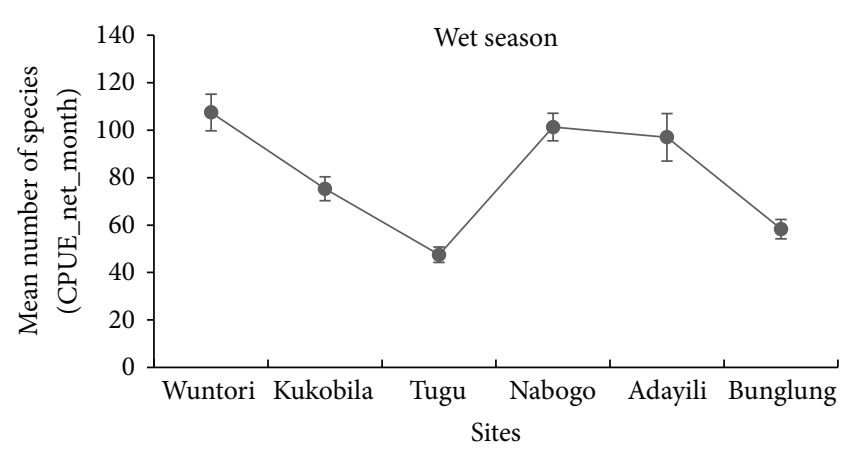

(b)

FIGURE 2: Variations in monthly catch per unit effort per net (CPUE) in the dry and wet season, across the six sites.

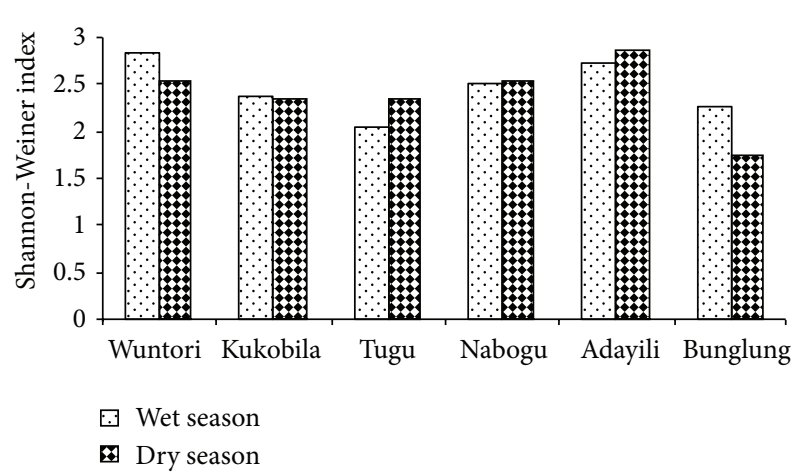

FIGURE 3: Variation in fish species diversity in the six wetlands for both dry season and wet season.

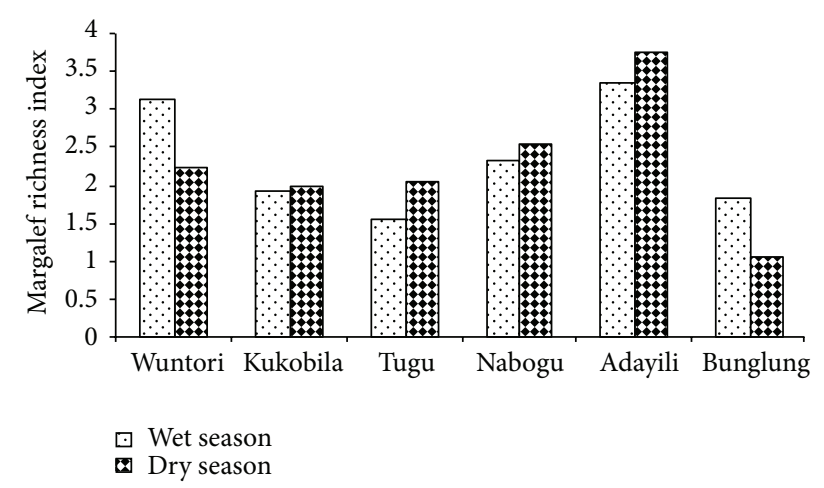

FIGURE 4: Seasonal changes of fish species richness in the six wetlands.

effort per net (CPUE) was consistently highest in Wuntori marsh, while the lowest CPUE was in Tugu and Bunglung constructed wetland (Figure 2).

Overall, CPUE did not vary significantly (Tukey HSD test, $p=0.27$ ) in the dry and wet seasons (Figure 2). Fish diversity and richness marginally differed in the six sites $(F=0.11, p=$ $0.03)$ in the dry $\left(H^{\prime}=2.395 \pm 0.366 ; D=2.395 \pm 0.366\right)$ and wet seasons $\left(H^{\prime}=2.354 \pm 0.738 ; D=2.354 \pm 0.738\right.$ ) (Figures 3 and 4). Trends in diversity and richness reflect in the resilience of each site to environmental disturbances. However, from individual sites, Wuntori $\left(H^{\prime}=2.7\right)$ and Adayilli $\left(H^{\prime}=2.6\right)$ wetlands were significantly diverse and species rich $(p<$ $0.05)$, compared to Bunglung constructed wetland $\left(H^{\prime}=2.0\right)$.

3.1. General Trends in Fish Structural Distribution in the Six Wetlands. The first two axes of the DCA (axis $1=42 \%$ and axis $2=27 \%$ ) jointly explained $69 \%$ of fish spatially varied distribution in the six sites (Figure 5). Fish community structure separated into three groups, as a result of habitat-specific conditions (Figure 5). Group 1 species from Bunlung man-made wetland (e.g., Synodontis velifer, Malapterurus electricus, and Auchenoglanis occidentalis) were generally less abundant in the wet and dry seasons and limited in their distribution. Farming activities, grazing intensity, water abstraction, and bush fires, were widespread in this site. Turbidity was equally high in both seasons, as were nutrient loads (phosphorus, ammonia, and nitrates). Fishes from this site survived low levels of nutrient loads, and showed a weak positive correlation with axis 1 (Figures 5 and 6). Fish communities in group II were from Nabogo and Adayili riparian systems and the shallow marshes of Tugu and Wuntori. Although species in this sites (e.g., Mormyrus rume, Bagrus bajad, Petrocephalus bovei, and Lates niloticus) were limited in their habitat distribution, their abundance were correlated with TDS ( $r=-0.40, p<0.05)$, calcium $(r=-0.41, p<0.05)$, and conductivity $(r=-0.41, p<$ 0.05 ) along axis 2 (Figure 6). High fish abundance at these sites reflects in their resilience to environmental disturbances like bushfires (Figures 5 and 6). Fish from group III were mainly from the deep marsh of Kubobila and dominated by Cichlids (e.g., Sarotherodon galilaeus, Oreochromis niloticus), Cyprinids (e.g., Labeo coubie), and Clariids (e.g., Clarias gariepinus). Surface water temperature did not significantly correlate with fish diversity and distribution, on axis $1(r=$ $0.19, p>0.05)$ or axis $2(r=0.37, p>0.05)$ (Figures 5 and 6 , Table 3).

The first two axes of the PCA jointly explained $81.84 \%$ of the seasonal variation in the structural distribution, abundance, and diversity of fishes in relation to the environmental variables (Table 2). Since axes 1 and $2(81.84 \%)$ cumulatively explained $>50 \%$ of variations in fish community structure and diversity [29], axis 3 correlation coefficient was not 


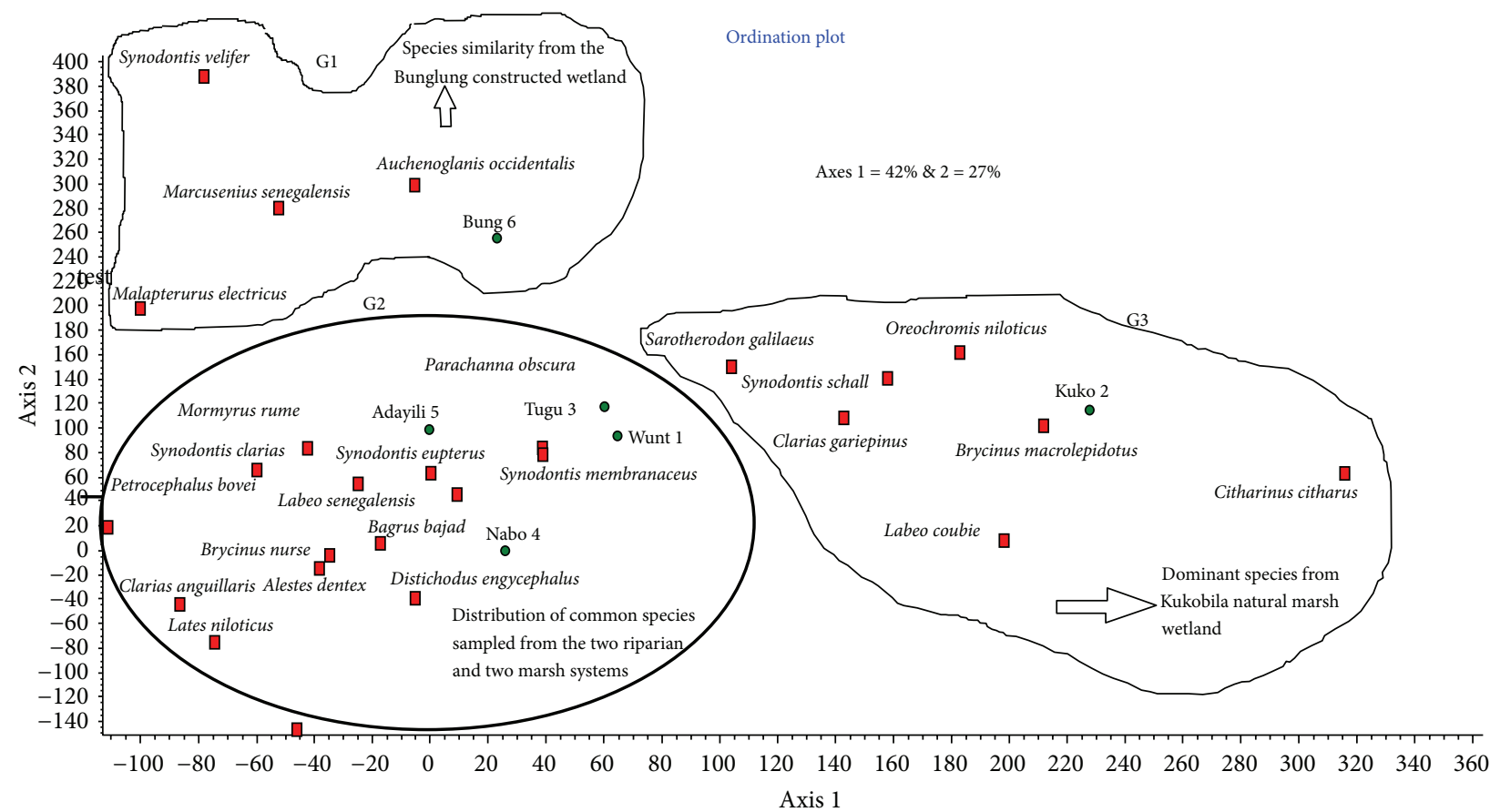

FIGURE 5: Detrended correspondence analysis (DCA) ordinations, showing fish community structure and distribution, into three groups. The red squares denote fish species, while the green circles denote sample sites. Environmental influences accounted for $69 \%$ of variations in fish community structure and distribution, while the remaining $31 \%$ was explained by a matrix of unidentified environmental and natural factors.

TABLE 3: Summary of PCA eigenvectors showing the levels of correlation with the first three axes of the environmental variables of the six sites. Asterisks $(*)$ indicate significance $(p<0.05)$, following Monte Carlo permutation procedures.

\begin{tabular}{|c|c|c|c|}
\hline & Axis 1 & Axis 2 & Axis 3 \\
\hline Conductivity & -0.122 & $-0.414^{*}$ & 0.152 \\
\hline TDS & -1.41 & $-0.404^{*}$ & 0.156 \\
\hline $\mathrm{pH}$ & -0.202 & -0.192 & -0.530 \\
\hline Nitrate-nitrogen & -0.335 & -0.165 & 0.080 \\
\hline Phosphate & -0.354 & -0.072 & 0.148 \\
\hline Ammonia & -0.199 & 0.205 & 0.284 \\
\hline Calcium & -0.077 & $-0.408^{*}$ & 0.249 \\
\hline Magnesium & -0.324 & -0.162 & -0.194 \\
\hline Dissolved oxygen & -0.235 & 0.298 & -0.258 \\
\hline Turbidity & 0.205 & 0.374 & 0.0004 \\
\hline Temperature & 0.190 & 0.374 & -0.540 \\
\hline Fire & -0.308 & -0.160 & -0.181 \\
\hline Grazing intensity & -0.342 & 0.060 & 0.085 \\
\hline Erosion & -0.338 & 0.141 & 0.075 \\
\hline Farming activities & -0.275 & 0.225 & -0.241 \\
\hline$\%$ total variance explained & 7.4 & 4.9 & 1.8 \\
\hline Cum $\%$ total variance explained $=81.83 \%$ (first two axes) & 49.1 & 32.8 & 11.9 \\
\hline
\end{tabular}

interpreted. Eigenvectors generated by axes 1 and 2 were significant $(Z$-score $=1.931 ; p<0.05 ; n=15)$ in influencing fish assemblage and diversity, following Monte Carlo permutation test. Environmental variables that caused maximum change in the six sites did not differ significantly $(F=0.158, \mathrm{df}=14$, and $p=0.98)$ (Figure 6).

\section{Discussion}

Our results revealed the direct and indirect influence of environmental disturbances on fish assemblages. High fish abundance and their structural distribution in Wuntori marsh and Adayili swamp forest systems were probably due to 


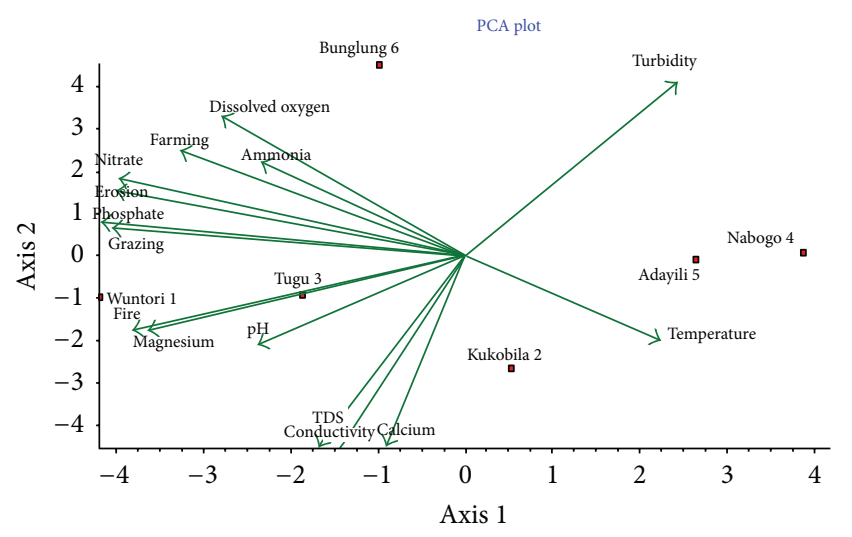

FIGURE 6: Principal component analysis (PCA) diagram, showing the significant correlations $(p<0.05)$ of environmental factors on fish community structure community and diversity in the six sites. The red squares represent the wetlands, while the arrows represent each of the environmental factors plotted pointing in the direction of maximum change of explanatory variables on a longitudinal gradient of the six sites. Axes $1=49.06 \%$ and Axes $2=32.77 \%$ jointly explained $81.83 \%$ influence of environmental variables on community structure, distribution, and diversity.

the migration of fish from the main course of the White Volta River into the wetlands via the tributaries, during cyclical inundation and the development of fish adaptive capacity to stress. We observed high diversity, richness, and abundance of the assemblage in Adayili forest swamp, although it contained lethal levels of ammonia $(0.6-1.9 \mathrm{mg} / \mathrm{L})$, which hitherto was lethal to fish survival and reproduction. Water temperature $\left(29^{\circ} \mathrm{C}\right)$ and average $\mathrm{pH}$ of 6.4 were relatively low at this site. A toxic effect of high ammonia $\left(\mathrm{NH}_{3}{ }^{+}\right)$ concentration on fish occurs only in prevailing higher $\mathrm{pH}$ values $(>7.0)$ and warmer temperatures $\sim 36^{\circ} \mathrm{C}$ in aquatic systems [30, 31]. Knepp and Arkin [32] observed that fish species can suffer gill damage even when ammonia levels are as low as $0.06 \mathrm{mg} / \mathrm{L}$, while at $0.2 \mathrm{mg} / \mathrm{L}$ levels, sensitive fish like trout and salmon begin to die. Other factors like distance from the source, elevation, number of ponds, channel type, substratum type, and land use are key determinants that influenced littoral fish abundance [33].

However, sites with low fish abundance (e.g., Tugu marsh and Bunlung constructed wetland) were probably a result of overfishing and broad scale disturbances such as farming, grazing activities, bushfires, and water chemistry, although less severe human-led activities and optimal physicochemical factors occur in the dry season and largely influenced fish abundances. Fish harvest in the wet season was prohibited (close season) to allow for spawning activities. Thus, only regulated fishing activities were permissible at a lesser spatiotemporal scale. Ayoola and Kuton [5] reported similar high abundance and biomass composition of fish species in the dry season, relative to the wet season in a Lagos lagoon. But Abban et al. [34] suggested that the lower fish abundance encountered in the wet season could be linked to the physical expansions of the wetlands found within the catchment of the White Volta River, where the current study was conducted.
Distribution of Bagrus bajad, Lates niloticus, Labeo coubie, and Brycinus macrolepidotus in preferred habitats was influenced by varied water quality parameters, bushfire, and grazing intensity. While species in the riparian systems appear to respond positively to turbid condition, we observed that species assemblages from the marshes and the constructed wetland were distributed along a longitudinal profile, with TDS, conductivity, nitrates, dissolved oxygen, water temperature, grazing intensity, and fire occurrence (Figures 5 and 6). Using a similar ordination approach, Pires et al. [3] found that water depth, isolated pools, and cover segregated fish species in the streams of the Guadiana basin in Portugal. Flooding regime [6] and habitat size $[35,36]$ have also been reported as important natural drivers of change that structure fish assemblages in streams. These contrasting findings to the current study could be attributed to the varied response of species-specific to inherent ecological factors from different biogeographical zones (i.e., temperate to topical zones).

Though farming activities were widespread in this study, it did not directly influence fish distribution (as shown by a weak axes correlation in Table 1) but indirectly led to an increase in turbidity in the riparian and the constructed wetlands. Argent and Carline [37] observed the increased in agricultural activities as a major factor influencing fish structure subwatersheds in Pennsylvania. Levels of orthophosphate and nitrate were low across the sites and probably contributed to the high abundance of fishes. In spite of the low level of nutrient loads, they were spatially auto correlated with grazing intensity and farming activities, suggesting the direct influence of these human-led activities. Highly eutrophic conditions impair fish fecundity and abundance, compared to less eutrophic areas [38].

Fish diversity indices at the six sites $\left(H^{\prime}=2.395 \pm 0.366\right.$ and $2.354 \pm 0.738$ ) reflected a highly diverse fish community compared to findings by Quarcoopome et al. [39] in Bontanga $\left(H^{\prime}=1.55\right)$ and Libga $\left(H^{\prime}=2.36\right)$ artificial wetlands, which are located within the same catchment of the current study. This appears to suggest that open natural habitats, characterized by a complex food web, support diverse fish species, compared to the artificial systems. But further comparison of the indices in this study to Fernandes and Achuthankutty [40] in the Salcete Taluka wetlands at Goa, India $\left(H^{\prime}=2.08-\right.$ 4.27 and 2.23-4.28), shows that species in the Salcete Taluka wetlands are resilient to environmental perturbation and natural factors, or the systems are less impacted. The near 100\% dominance of Sarotherodon galilaeus for the cichlids probably suggests their endemic nature in Northern wetlands, as a result of their broad scale tolerance to varying degrees of ecological stress conditions. This species may be considered as a suitable bioindicator candidate to impacts of wetland disturbances such as pollution and climate change. Similar observations on all year round dominance of Cichlids in the Lagos lagoon were documented by Ayoola and Kuton [5].

\section{Conclusion}

Although fish abundance and diversity were reasonably high in Wuntori, Adayili, and Nabogo, their spatial distributions were limited. Seasonal variability in diversity, richness, and 
abundance was as a result of varied habitat conditions mediated by environmental disturbances such as farming activities and bushfires. Most species appeared to be tolerant to low nutrient loads and this partly contributed in the high abundance and diversity. Finally, the low nutrient loads also suggest that the wetlands were not polluted. The implication of these results suggests that wetland managers must consider instituting conservation measures to check land use activities that has tendency to cause future eutrophication condition. The implementation of these conservation measures could contribute to the increase and sustenance of fish population, which serve as a major source of livelihoods for the rural dwellers.

\section{Competing Interests}

The authors declare that there are no competing interests regarding the publication of this paper.

\section{Acknowledgments}

The authors express their profound gratitude to the Ghana Education Trust Fund (GETFund), for their financial support of the research work.

\section{References}

[1] C. H. Hocutt and E. O. Wiley, Eds., The Zoogeography of North American Freshwater Fishes, John Wiley \& Sons, New York, NY, USA, 1986.

[2] Millennium Ecosystem Assessment, Ecosystems and Human Well-Being: Wetlands and Water Synthesis, World Resources Institute, Washington, Wash, USA, 2005.

[3] A. M. Pires, I. G. Cowx, and M. M. Coelho, "Seasonal changes in fish community structure of intermittent streams in the middle reaches of the Guadiana basin, Portugal," Journal of Fish Biology, vol. 54, no. 2, pp. 235-249, 1999.

[4] K. J. Killgore and J. J. Hoover, "Effects of hypoxia on fish assemblages in a vegetated waterbody," Journal of Aquatic Plant Management, vol. 39, no. 1, pp. 40-44, 2001.

[5] S. O. Ayoola and M. P. Kuton, "Seasonal variation in fish abundance and physicochemical parameters of Lagos Lagoon, Nigeria," African Journal of Environmental Science and Technology, vol. 3, no. 5, pp. 149-156, 2009.

[6] K. D. Fausch and R. G. Bramblett, "Disturbance and fish communities in intermittent tributaries of a Western Great Plains river," Copeia, vol. 1991, no. 3, pp. 659-674, 1991.

[7] I. G. Cowx and R. L. Welcomme, Eds., Rehabilitation of Rivers for Fish, Blackwell Science, Oxford, UK, 1998.

[8] B. W. Menzel, J. B. Barnum, and L. M. Antosch, "Ecological alterations of Iowa prairie agricultural streams. Iowa State," Journal of Science, vol. 59, pp. 5-30, 1984.

[9] H. E. Berkman and C. F. Rabeni, "Effect of siltation on stream fish communities," Environmental Biology of Fishes, vol. 18, no. 4, pp. 285-294, 1987.

[10] P. L. Angermeier and M. R. Winston, "Characterizing fish community diversity across Virginia landscapes: prerequisite for conservation," Ecological Applications, vol. 9, no. 1, pp. 335349, 1999.
[11] J. Lyons, "Patterns in the species composition of fish assemblages among Wisconsin streams," Journal of Environmental Biology of Fishes, vol. 45, no. 4, pp. 329-346, 1996.

[12] K. Pivnička and M. Humpl, "Fish assemblages in the Elbe River watershed-species richness, frequency, and clusters," Acta Universitatis Carolinae Environmentalica, vol. 18, no. 1-2, pp. 107-116, 2004.

[13] Z. A. Ansari, A. Chatterji, B. S. Ingole, R. A. Sreepada, C. U. Rivonkar, and A. H. Parulekar, "Community structure and seasonal variation of an inshore demersal fish community at Goa, West Coast of India," Estuarine, Coastal and Shelf Science, vol. 41, no. 5, pp. 593-610, 1995.

[14] A. Chezhian, N. Kabilan, T. Suresh-Kumar, and D. SenthamilSelvan, "Influence of different calcium levels and low $\mathrm{pH}$ of water on the plasma electrolyte regulation of a fresh water teleost fish Cyprinus carpio Var. communies, (Linnaeus, 1958)," Current Research Journal of Biological Science, vol. 3, no. 2, pp. 147-154, 2011.

[15] A. Y. Karikari, K. A. Asante, and C. A. Biney, "Water quality characteristics at the Estuary of Korle Lagoon in Ghana," West Africa Journal of Applied Ecology, vol. 10, pp. 73-85, 2006.

[16] C. A. Nsor and E. A. Obodai, "Environmental determinants influencing seasonal variations of bird diversity and abundance in Wetlands, Northern Region (Ghana)," International Journal of Zoology, vol. 2014, Article ID 548401, 10 pages, 2014.

[17] A. T. Charles, T. R. Brainerd, M. A. Bermudez, H. M. Montalvo, and R. S. Pomeroy, Fisheries Socioeconomics in the Developing World: Regional Assessments and an Annotated Bibliography, International Development Research Centre (IDRC), Ottawa, Canada, 1994.

[18] T. Slaymaker and R. M. Blench, Rethinking Natural Resource Degradation in Sub-Saharan Africa: Policies to Support Sustainable Soil Fertility Management, Soil and Water Conservation among Resource Poor Farmers in Semi-arid Areas: Country Studies, University for Development Studies, Tamale, Ghana, 2002.

[19] H. R. Dankwa, E. K. Abban, and G. G. Teugels, Freshwater Fishes of Ghana. Identification, Distribution, Ecological and Economic Importance, vol. 283 of Annales Science Zoologiques, 1999.

[20] D. Paugy, C. Leveque, and G. G. Teugels, Eds., The Fresh and Brackish water Fishes of West Africa, Publications Scientifiques du Museum, MRAC. IRD Editions. Africa. Tervuren, 2004.

[21] APHA (American Public Health Administration), Standard Methods for the Examination of Water and Wastewater, APHA (American Public Health Administration), Washington, DC, USA, 20th edition, 1998.

[22] N. Salafsky, D. Salzer, A. J. Stattersfield et al., "A standard lexicon for biodiversity conservation: unified classifications of threats and actions," Conservation Biology, vol. 22, no. 4, pp. 897-911, 2008.

[23] C. Battisti, L. Luiselli, and C. Teofili, "Quantifying threats in a Mediterranean wetland: are there any changes in their evaluation during a training course?" Biodiversity and Conservation, vol. 18, no. 11, pp. 3053-3060, 2009.

[24] C. E. Shannon and W. Wiener, The Mathematical Theory of Communication, Urbana University Illinois Press, Champaign, Ill, USA, 1963.

[25] R. Margalef, Perspective in Ecological Theory, University of Chicago Press, Chicago, Ill, USA, 1968.

[26] P. A. Henderson and R. M. Seaby, Community Analysis Package 1.14, S041 8GN, Pisces Conservation Ltd. IRC House, Pennington, UK, 1999. 
[27] M. Kent and P. Coker, Vegetation Description and Analysis. A Practical Approach, John Wiley \& Sons, Chichester, UK, 1992.

[28] K. McGarigal, S. Cushman, and S. Stafford, Multivariate Statistics for Wildlife and Ecology Research, Springer, New York, NY, USA, 2000.

[29] C. J. F. terBraak, "Canonical correspondence analysis: a new eigenvector technique for multivariate direct gradient analysis," in Multivariate Statistics for Wildlife and Ecology Research, K. McGarigal, S. Cushman, and S. Stafford, Eds., p. 700, Springer, New York, NY, USA, 2000.

[30] US-EPA, "Ambient water quality criteria for ammonia," EPA Report 440/5-85-001, United States Environmental Protection Agency, Washington, DC, USA, 1984.

[31] Canadian Water Quality Guidelines for the Protection of Aquatic Life, Canadian Council of Ministers of the Environment, 2010.

[32] G. L. Knepp and G. F. Arkin, "Ammonia toxicity levels and nitrate tolerance of channel catfish," The Progressive FishCulturist, vol. 35, no. 4, pp. 221-224, 1973.

[33] M. Humpl and K. Pivnička, "Fish assemblages as influenced by environmental factors in streams in protected areas of the Czech Republic," Ecology of Freshwater Fish, vol. 15, no. 1, pp. 96-103, 2006.

[34] "Biodiversity, management and utilization of West African Fishes," in Proceedings of the World Fish Center Conference Proceedings, E. K. Abban, C. M. V. Casel, P. Dugan, and T. Falk, Eds., p. 63, Penang, Malaysia, 2004.

[35] L. R. Brown, "Fish communities and their associations with environmental variables, lower San Joaquin River drainage, California," Environmental Biology of Fishes, vol. 57, no. 3, pp. 251-269, 2000.

[36] G. Grenouillet, D. Pont, and C. Hérissé, "Within-basin fish assemblage structure: the relative influence of habitat versus stream spatial position on local species richness," Canadian Journal of Fisheries and Aquatic Sciences, vol. 61, no. 1, pp. 93102, 2004.

[37] D. G. Argent and R. F. Carline, "Fish assemblage changes in relation to watershed," Journal of Aquatic Ecosystem Health Management, vol. 7, no. 1, pp. 101-114, 2004.

[38] A. Sandström and P. Karås, "Effects of eutrophication on youngof-the-year freshwater fish communities in coastal areas of the baltic," Environmental Biology of Fishes, vol. 63, no. 1, pp. 89-101, 2002.

[39] T. Quarcoopome, F. Amevenku, and O. Ansa-Asare, "Fisheries and limnology of two reservoirs in Northern Ghana," West African Journal of Applied Ecology, vol. 12, no. 1, 2008.

[40] B. Fernandes and C. T. Achuthankutty, "Seasonal variation in fishery diversity of some wetlands of the Salcete Taluka, Goa, India," Indian Journal of Marine Sciences, vol. 39, no. 2, pp. 238247, 2010 . 

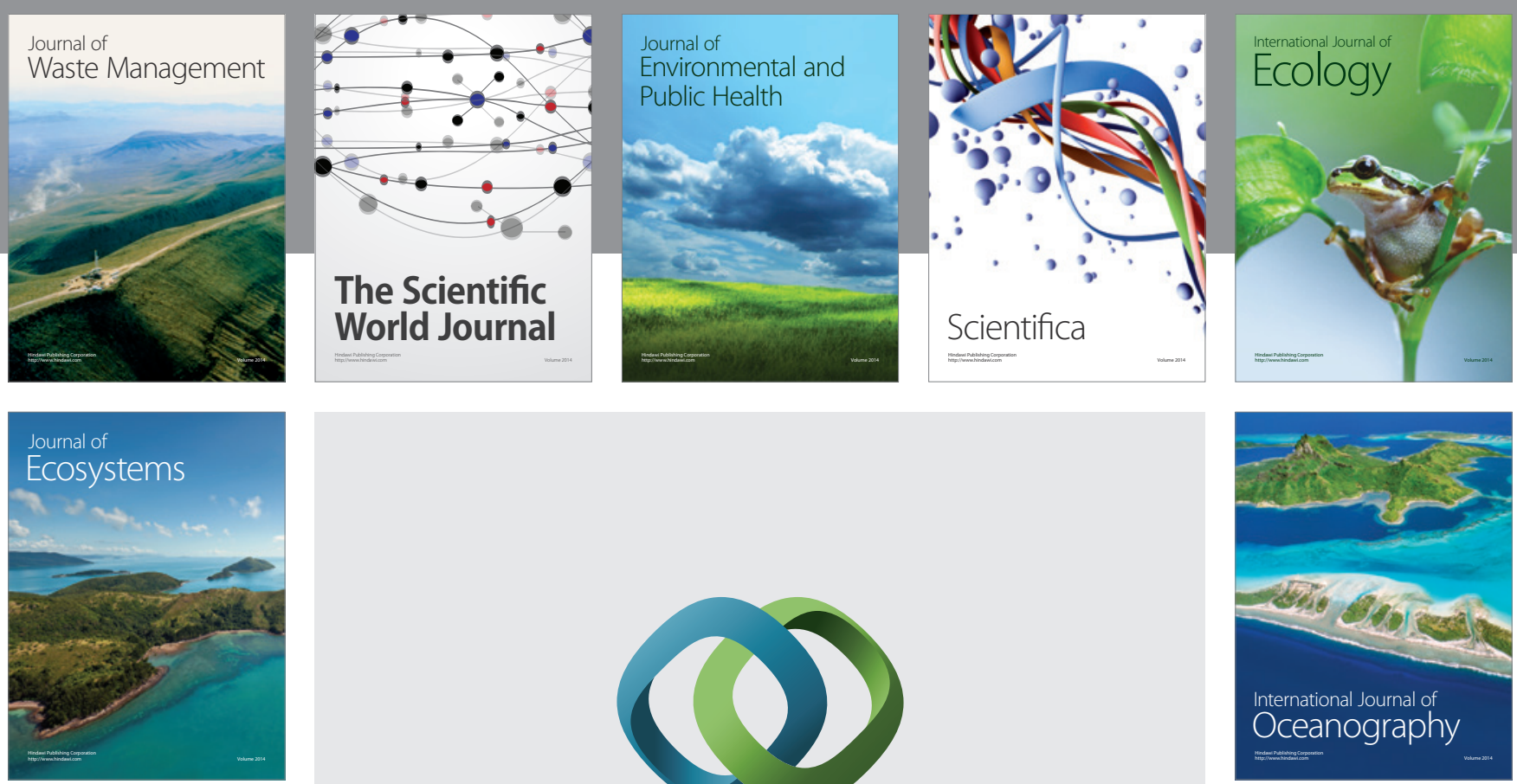

The Scientific World Journal
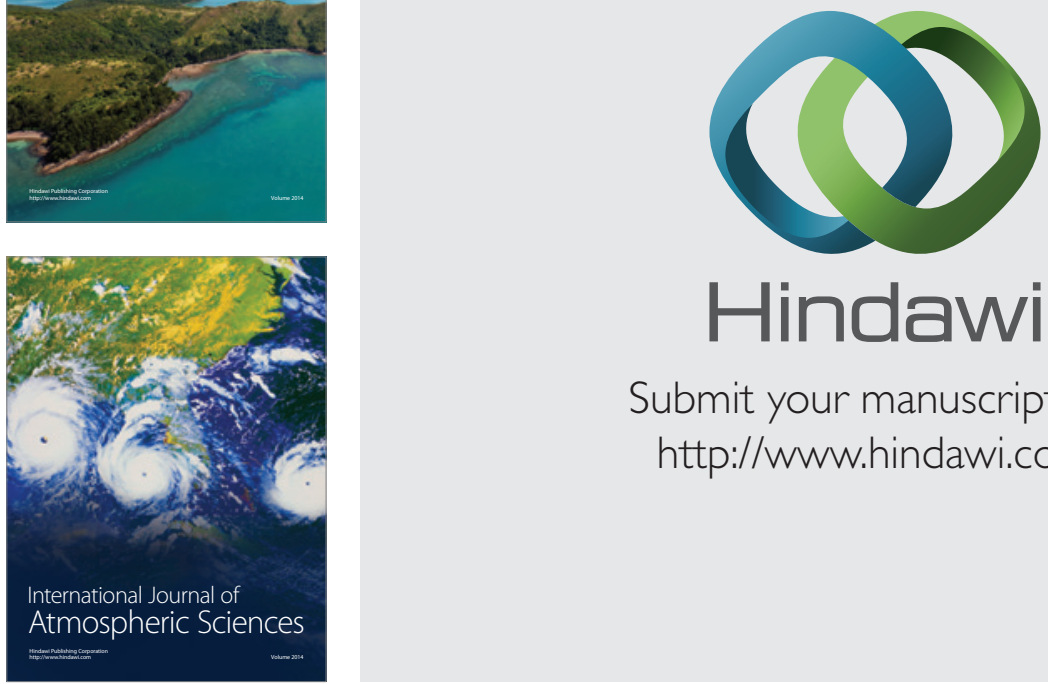

\section{Hindawi}

Submit your manuscripts at

http://www.hindawi.com
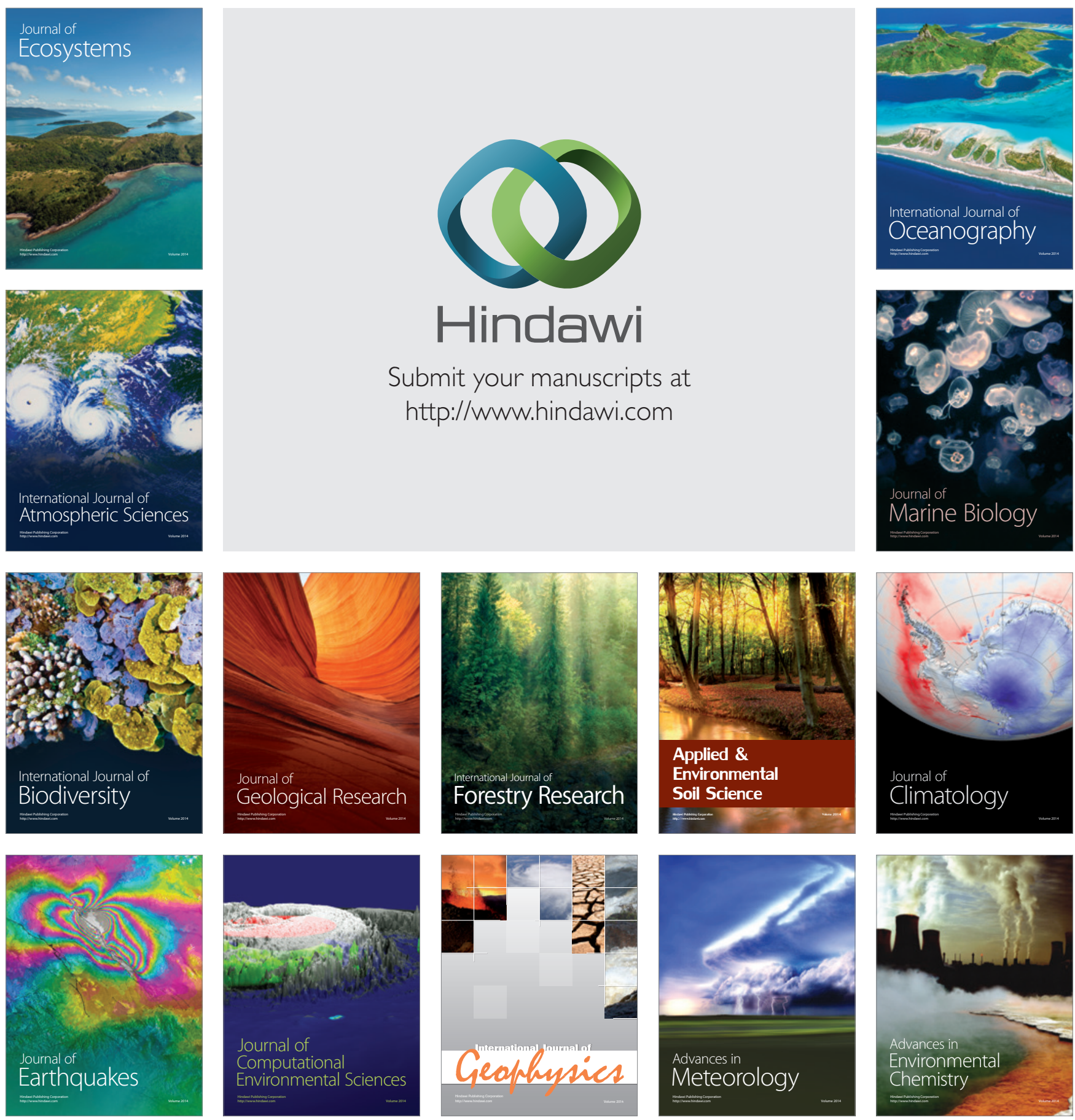